\title{
The Impact of International Outsourcing on U.S. Workers' Wages: Rethinking the Role of Innovation
}

\author{
Kuang-Chung $\mathrm{Hsu}^{1} \&$ Hui-Chu Chiang ${ }^{1}$ \\ ${ }^{1}$ Department of Economics, University of Central Oklahoma, USA \\ Correspondence: Kuang-Chung Hsu, Department of Economics, University of Central Oklahoma, 100 North 100 \\ University Drive, Edmond, OK 73034, USA. Tel: 1-405-794-5261. E-mail: khsu1@uco.edu
}

Received: January 24, 2014

Accepted: March 5, 2014

Online Published: April 25, 2014

doi:10.5539/ijef.v6n5p1

URL: http://dx.doi.org/10.5539/ijef.v6n5p1

\begin{abstract}
The purpose of this paper is to extend Feenstra and Hanson's (1999) analysis of the impact of international outsourcing on wages by considering quality ladders and product cycles theory. Glass and Saggi (2001) found that international outsourcing induces greater incentives for innovation. Hsu (2011) employed a dynamic general equilibrium model to illustrate that outsourcing may affect skilled workers who conduct research and development (R\&D) differently from the way it influences skilled workers in manufacturing departments. This paper employs U.S. manufacturing data and finds that international outsourcing increased the wage of skilled workers who conducted R\&D in both the 1970s and the 1980s. Outsourcing and expenditure on R\&D also increased the relative wages of white-collar workers who are skilled labor but not related to R\&D works in the 1980s. The wages of white-collar labor were not increased by international outsourcing in the 1970s.
\end{abstract}

Keywords: international outsourcing, wage inequality, innovation, two-stage regression

\section{Introduction}

In the previous two decades, outsourcing and similar subjects have received a great deal of attention from economists (Note 1). Within-country wage divergence in source (or home) countries has been thought to be one of the effects on labor markets caused by outsourcing. Theoretically speaking, outsourcing firms substitute domestic unskilled labor (or labor) with foreign unskilled labor and push producers toward skilled-labor-intensive (or capital-intensive) production, which leads to a decrease in the wages of domestic unskilled labor and increases the wages of skilled labor. Literature such as Slaughter (1995), Feenstra and Hanson (1997), Jones and Kierzkowski (2001), Egger and Kreickemeier (2008), and Sayek and Sener (2006) has supported this argument. Empirical literature struggled to find the wage inequality caused by outsourcing until Feenstra and Hanson $(1996 ; 1999)$ adopted a new measurement of outsourcing and found that outsourcing could account for $30.9 \%$ of the change of the non-production wage share and $15 \%$ of the increase in the relative wages of non-production workers during the period 1979-1990 in the United States (Note 2).

There is, however, one unexpected result in Feenstra and Hanson (1996): They can only illustrate the effects of outsourcing on the labor market by employing U.S. data from the 1980s. In the regression results from the 1970s, the effect of outsourcing on the relative wage share of skilled labor to unskilled labor is insignificant and negative. Therefore, the conclusion that outsourcing always raises the wage of skilled labor relative to unskilled labor has an exception. Arndt (1997) argued that even in capital-abundant countries the employment and wages of labor would rise if labor-intensive industry were outsourced, explaining that outsourcing gives producers an advantage against foreign rivals in the end-products market, and the gain from trade enhances the employment in industries that make use of it. Jones (2005) also thought that if the home country has a high proportion of skilled labor to unskilled labor, outsourcing could decrease the relative wage of skilled labor relative to unskilled labor. Thus it seems that the unexpected results in Feenstra and Hanson (1996) can be explained theoretically.

Two additional questions still remain. First, outsourcing, which is thought of as a technological improvement, pushes production toward skilled-labor-intensive production. Thus it should benefit skilled labor the most. Even though outsourcing did not result in all skilled laborers benefiting from outsourcing, some skilled workers should still benefit from it.

Glass and Saggi (2001) followed Grossman and Helpman's (1991) quality ladders and product cycles model in 
discussing the outsourcing effects on wages and innovation activities. In the quality ladders and product cycles model, a new generation of products starts with innovation, then production. Glass and Saggi (2001) concluded that "outsourcing lowers the marginal cost of production and thus increases profits, creating greater incentives for innovation." Thus, skilled workers who conduct research and development (R\&D) should always benefit from outsourcing. Hsu (2011) employed data from the National Bureau of Economics Research (NBER) and the National Science Foundation (NSF) to show that from 1970 to 1996 scientists, who were the skilled labor involved in R\&D work, received a different share of the increase in the wage bill from that of the white-collar workers whose job are not related to $R \& D$.

Based on the facts, Hsu (2011) extended the works of Glass and Saggi (2001) and Sayek and Sener (2006) works by differentiating scientists who only conduct R\&D work from white-collar workers. He argued that an increase in outsourcing could increase or decrease the wages of white-collar workers in the outsourcing parent country, depending on whether outsourcing firms are skilled-labor intensive or unskilled-labor intensive; but international outsourcing always increases the wage of scientists. Thus, the insignificant and negative results for the 1970s in Feenstra and Hanson (1996) could be a mixed result of a positive effect on scientists and a non-positive effect on white-collar workers. This paper tests empirically the effects of international outsourcing on laborers who conduct R\&D works (hereafter: R\&D workers); and the results support the idea proposed by Hsu (2011).

Second, a follow-on question after splitting R\&D workers from skilled labor is what the difference in relative wages between white-collar workers and blue-collar workers was in the 1970s and 1980s for U.S. manufacturing industries. Was that difference greater or less than that of the relative wages of non-production and production workers computed by Feenstra and Hanson (1999)?

In sum, the focus of this study is, first, to empirically test whether outsourcing affects R\&D workers differently from the way it affects skilled labor in manufacturing production, and second, following Feenstra and Hanson's (1999) two-stage regressions method, to see what the change in the relative wage of white-collar and blue-collar workers is in both the 1970s and 1980s after screening R\&D workers from other skilled labor.

\section{The Model}

\subsection{Model Structure}

The analysis in this paper is based on the model structure of quality ladders and product cycles theory. Most modeling equations can be found in Hsu (2011) and will not be repeated in this paper, except for the equations of innovation intensity, manufacturing cost, and labor markets.

The model posits two countries, the North and the South. The North is a developed country and outsources part of the production to the developing country, the South. Each country has a representative consumer and an infinite number of firms. All Northern firms can be divided into two industries by their outsourcing preference. The first type of industry is willing to outsource and the other is not. Firms in the North attempt to develop a higher-quality product and win the innovation competition to capture the entire market. To conduct R\&D, firms need to hire R\&D workers, who exist only in the North. Let $w^{R D}$ be the wage of R\&D workers; $a_{j}^{R D}$ represents the labor requirement per innovation intensity in type $j$ industry. To undertake an innovation of intensity $r_{j}$ for the time period $d t$ has a cost of $w^{R D} a_{j}^{R D} r_{j} d t$. The cost of an innovation should be less than or equal to the reward created by the innovation for a finite intensity of innovation to obtain.

$$
V_{j}^{N} \leq w^{R \& D} a_{j}^{R D} \text { with equality whenever } r>0 \text { and } j=1,2
$$

where $V_{j}^{N}$ is the market value of an industry-leading Northern firm. After winning the innovation competition, the firm can start producing its products by hiring white-collar and blue-collar workers.

Let $w_{N}^{W}$ and $w_{N}^{B}$ be the wage of white-collar and blue-collar workers in the North. The unit cost of production is

$$
A C_{j}^{N}=a_{j}^{N W}\left(W^{N}\right) W_{N}^{W W}+a_{j}^{N B}\left(W^{N}\right) W_{N}^{B} \quad 0<a^{N}<1 \text { and } j=1,2
$$

where $a_{j}^{N W}$ and $a_{j}^{N B}$ are the white- and blue-collar workers' unit labor requirements in type $j$ industry; $w^{N}$ defined as $w_{N}^{W} / w_{N}^{B}$ is the ratio of Northern white-collar workers. Note that $\partial a_{f}^{N W} / \partial w^{N}<0$ and $\partial a_{f}^{N B} / \partial w^{N}>0$. Since the wages of Southern workers are lower than those of Northern workers, the Northern firm can choose to outsource proportion $\alpha$ of its labor to the South. Undertaking outsourcing intensity $\phi$ for a 
time interval $d t$, a Northern firm can successfully transfer labor to an outsourcing firm with exogenous probability $\phi d t$. Let $a_{1}^{O W}$ and $a_{1}^{O B}$ be the unit labor requirement for white- and blue-collar workers' of an outsourcing firm in type 1 industry and $a^{S W}$ and $a^{S B}$ be the white- and blue-collar workers' unit labor requirement for Southern firms that receive contracts from outsourcing firms. The unit cost of an outsourcing firm is

$$
\left.A C_{1}^{O}=(1-\alpha) \mid a_{1}^{O W}\left(w^{N} ; \alpha\right) w_{N}^{W}+a_{1}^{O B}\left(w^{N} ; \alpha\right) w_{N}^{B}\right\rfloor+\alpha\left\lfloor a^{S W}\left(w^{S}\right) w_{S}^{W}+a^{S B}\left(w^{S}\right) w_{S}^{B}\right\rfloor
$$

where $w^{S}=w_{S}^{W} / w_{S}^{B}$ and $\partial a_{1}^{O W} / \partial \alpha>0$ and $\partial a_{1}^{O B} / \partial \alpha<0$ (Note 3).

In the Northern labor market, the total labor demand for each type of labor equals the fixed labor supply. Let $\overline{L^{R D}}, \overline{L_{N}^{W}}, \overline{L_{N}^{B}}$ denote the fixed labor supply of $\mathrm{R} \& \mathrm{D}$, white-collar workers, and blue-collar workers; the labor-market equations are

$$
\begin{gathered}
\sum_{j} a_{j}^{r} r \equiv \overline{L^{R D}}, j=1,2 \\
{\left[\sum_{j} a_{j}^{N W}\left(w^{N}\right)+(1-\alpha) a_{1}^{O W}\left(w^{N}\right)\right] E=\overline{L_{N}^{W}}, j=1,2} \\
{\left[\sum_{j} a_{j}^{N B}\left(w^{N}\right)+(1-\alpha) a_{1}^{O B}\left(w^{N}\right)\right] E=\overline{L_{N}^{B}}, j=1,2}
\end{gathered}
$$

where $E$ is defined as the total expenditure divided by the price of the newest general product. After solving the model, the innovation intensity of type 1 industry can be shown as $r_{1}=f\left(\alpha, \phi, w^{N^{*}}\right)$, where $w^{N^{*}}$ is the equilibrium Northern relationship of the wages of white-collar to those of blue-collar workers; this has an indirect effect on $r_{1}$. The outsourcing fraction, $\alpha$, has directly positive effects on the innovation intensity. The effects of an increase in $\alpha$ on the wage of R\&D workers is mainly determined by the positive innovation effect caused by the change of $r_{1}$. The effect of an increase in $\alpha$ on the relative wage of Northern white-collar workers depends on whether the outsourcing industry is white-collar intensive or blue-collar intensive (Note 4). If the outsourcing industry is more white-collar-worker intensive than the non-outsourcing industry, the relative wage of white-collar workers is increased.

\subsection{Empirical Methodology}

As discussed above, outsourcing increases the intensive of R\&D directly and also raises R\&D workers' wages, and then outsourcing improves the productivity of and influences the demand for commodities (Note 5), which makes the relative wage of white-collar to blue-collar workers change. This study tests the effect of outsourcing on R\&D workers' wages first and then follows the two-stage regression in Feenstra and Hanson (1999) to deal with the second issue.

\subsubsection{R\&D Workers' Wage Regression}

The dependent variable in the wage regressions are the change in $\log R \& D$ workers' wages. In addition to outsourcing, this study also includes explanatory variables such as change in log real output and change in log capital/output ratio and those structural variables in Feenstra and Hanson (1999), which are computer share and high-tech share (difference) (Note 6). Those explanatory variables are put in the regressions to capture the effect of output, capital, and high technology on the wages of R\&D workers. The wage regressions of R\&D workers can be written as

$$
\Delta W_{i t}^{R \& D}=\phi^{\prime} \Delta K_{i t}+\varepsilon_{i t}
$$

where $\Delta W_{i t}^{R \& D}$ is the change in log R\&D workers' wages and $\Delta K_{i t}$ is a vector of the change of explanatory variables.

\subsubsection{Two-Stage Regression}

Two-stage regressions are employed in this analysis primarily because outsourcing and other explanatory variables affect factor prices by influencing the price of the commodity and productivity first. Then the changes in the commodity's price and productivity implied by those structural variables influence factors' prices. The changes in the price and productivity implied by those structural variables, however, are not measurable, but they 
can be estimated by performing a regression of the commodities' prices and productivity on the changes of structural variables. Feenstra and Hanson (1999) argue, however, that the sign of product prices cannot be easily predicted, since the closed-form solution does not exist. Intuitively speaking, if outsourcing industries produce goods that are low-skilled labor intensive, outsourcing part of production to developing countries should reduce its cost on the wage bill and will probably reduce product prices. On the other hand, if outsourcing industries produce goods that are high-skilled labor intensive, the effect of cost reduction may not suppress the effect of technological improvement. The price could increase or experience no change (Note 7).

Value-added price here is different from that in Feenstra and Hanson (1999), since R\&D expense should be thought of as a sunk cost that needs to be paid before production. The primary factors in this paper are white-collar workers, blue-collar workers, and capital. Value-added prices that exclude R\&D workers can be obtained by

$$
\Delta \ln P_{i t}^{V A-R D}=\left\lfloor\Delta \ln P_{i t}^{Y}-0.5\left(S_{i t}^{M E}+S_{i t-1}^{M E}\right) \Delta \ln P_{i t}^{M E}\right\rfloor / 0.5\left(S_{i t}^{V A-R D}+S_{i t-1}^{V A-R D}\right)
$$

where $P_{i t}^{V A-R D}$ and $P_{i t}^{Y}$ are value-added and output price excluding R\&D in industry $i=1, \ldots, \mathrm{N} . S_{i t}^{M E}$ denotes the cost-share of intermediate input in industry $i=1, \ldots$, N. $P_{i t}^{M E}$ denotes intermediate input prices, and $S_{i t}^{V A-R D}$ denotes the cost share of the value added, excluding R\&D cost.

The new state-of-the-art technology invented by R\&D workers can improve the industry's productivity and increase product prices. Thus, $R \& D$ expenditure to total output should be included in the structural variables while the two-stage regression is run. Conducting $R \& D$ requires high-technology facilities and $R \& D$ workers. High-technology capital can be captured by high-technology share (difference) and computer share. The wage share of R\&D can be represented by R\&D payment share, which is computed by total expense in the wage bill of $R \& D$ workers divided by the industry's value of shipment. R\&D payment share, however, is also influenced by outsourcing, computer, and high-technology share (difference). The relationship of R\&D share in the wage bill to structural variables is

$$
S_{i t}^{R D}=\alpha^{\prime} \Delta Z_{i t}+R D_{i t}
$$

where $S_{i t}^{R D}$ is R\&D workers' payment share in the total value of shipment, $\alpha$ is a vector of coefficients, $\Delta Z_{i t}$ is a vector of the change of structure variables, and $R D_{i t}$ is a residual term that captures all the other determinants to $\mathrm{R} \& \mathrm{D}$ payment share, which is assumed orthogonal to $Z_{i t}$. If the first-stage regression also takes $\mathrm{R} \& \mathrm{D}$ payment share into consideration, then the regression should become

$$
\Delta \ln P_{i t}^{V A}+E T F P_{i t}=\beta^{\prime} \Delta Z_{i t}+\gamma^{\prime} S_{i t}^{R D}+\varepsilon_{i t}
$$

where the ETFP ${ }_{i t}$ is Effective Total Factor Productivity (ETFP). Placing equation (9) in Feenstra and Hanson's (1999) first-stage regression yields the following equation:

$$
\Delta \ln P_{i t}^{V A}+E T F P_{i t}=\phi^{\prime} \Delta Z_{i t}+\gamma^{\prime} R D_{i t}+\varepsilon_{i t}
$$

where $\phi=\beta+\alpha \gamma$. Let $R D_{i t}$ stand for R\&D factors; its coefficient $\gamma$ can tell us the impact of R\&D wage payment on dependent variables. Since spending on R\&D can enhance technology, the coefficient $\gamma$ is expected to be positive. A dummy variable that captures grouping effects is also added, and correlation between two-digit industries is allowed when this study estimates equations (9) and (11).

In the second-stage regression, there is an estimation issue addressed by Feenstra and Hanson (1999). Since the dependent variable in the second-stage regression is constructed from the first-stage regression, the disturbance terms in the second-stage regression will be correlated across observations. Feenstra and Hanson (1999) suggest a procedure to correct the standard errors in the second-stage regression. Dumont et al. (2005) find that their correcting method is negatively biased and leads to overestimation of the inferred significance and suggest computing an unconditional variance instead (Note 8). Standard errors in the second-stage regression of this paper follow the method of Dumont et al. (2005).

\section{Data}

\subsection{Data Source and Coordination}

According to the NSF, R\&D is mainly done by R\&D workers, who are scientists and engineers, and supporting personnel, such as technicians and craftsmen. Although the NSF can provide the wage cost and employment figures of R\&D in two- and three-digit industries from 1953, their data still cannot be employed in this study for 
the following reasons: First, even though the NSF can provide us the number of full-time-equivalent (FTE) scientists and engineers by industry, it has not separated the wage data of scientists from that of engineers and supporting personnel since 1976. This makes the wages of R\&D workers unknown. Second, to avoid possible disclosure of information about the operations of individual companies, some industries' data are being withheld for a few years. Thus, this study has to employ another data source to divide skilled labor.

The Current Population Survey (CPS) provides information about workers in the United States regarding their occupations, industries, and wage incomes. The occupation information can be employed to distinguish R\&D workers from other white-collar workers. In addition, since 1976 the March CPS supplement can provide data about hours worked (Note 9). The NBER Productivity Database includes the value of shipment, a price deflator for value of shipments, number of employees, number of production worker hours, and number of production workers in 445 manufacturing industries in the 1972 four-digit Standard Industrial Classification (SIC) (Note 10) Since the NBER Productivity Database only covers non-production (skilled labor) and production workers (unskilled labor), this study employs the CPS data as an auxiliary source to divide non-production workers into $\mathrm{R} \& \mathrm{D}$ workers and white-collar workers. However, there are some issues related to data consistency that need to be dealt with before the division is performed.

First, the production/non-production data in the NBER Productivity Database comes from the Annual Survey of Manufactures (ASM), and its production/non-production classification is different from the white-collar/blue-collar classification in the CPS. Berman, Bond, and Griliches (1994) compared the classification of the CPS to that of the ASM and found that these two categories are similar in that they rose together from 1973 until 1987, with the discrepancy never more than two percentage points. Second, the Bureau of Labor Statistics (BLS) changed the census occupational and industrial classification every ten years between 1970 and 1990 (Note 11). This study chooses the 1980 census occupational and industrial classification system as the main one and applies it to the other classification systems. Then, I converted the 1980 census industrial classification to the 1972 three-digit SIC classification (Note 12). Third, the March CPS supplement provides information regarding respondents' wages and hours worked in the previous year. The number of employees in each industry, which can be computed by a headcount of respondents in each industry, however, indicates the current year. For consistency, this study excludes those respondents who did not have wage income last year. Thus, all the data regarding wages, employment, and working hours in each year present information for the previous year.

Even though Berman, Bond, and Griliches (1994) found the difference between the two databases small, the wage shares from the CPS are still higher than those from the NBER Productivity Database. That means that some occupations in the CPS classification of white-collar workers should be included with the production workers. Technicians (213-235), who are also in charge of maintenance and repair, are classified as white-collar workers in the classification of occupations in the CPS, but according to the definition of production workers in ASM (Note 13), they are production workers. After the technicians are re-categorized as blue-collar workers, the wage shares computed from the CPS are closer to those computed from the NBER Productivity Database (Note 14).

To properly put outsourcing in the independent variables, this study follows the work of Feenstra and Hanson (1999), which has two types of measures of outsourcing. The outsourcing fraction is the imported purchases of intermediate material divided by total consumption (Note 15). The broad measure of outsourcing considers all industries' inputs purchased from other four-digit SIC manufacturing industries, and the narrow measure of outsourcing considers only the industries' inputs purchased from the same two-digit SIC industries. Both outsourcing (narrow) and outsourcing (difference) are used in this study; the variable outsourcing (difference) is the difference between the narrow measure of outsourcing and the broad measure of outsourcing.

\subsection{The Definition of R\&D Workers}

Even though a respondent's occupation is engineer or scientist, he or she is not necessarily involved in R\&D. Some skilled workers not included in this classification of R\&D workers actually are involved in R\&D. Economists, for example, are in charge of performing economic analyses of the implementation and planning of R\&D projects. A designer who is responsible for designing the appearance of new products should also be considered an R\&D worker. Therefore, this study has two definitions of R\&D workers. The first group, referred to as narrowly defined $R \& D$ workers, consists of the occupations in which a high proportion of workers are doing R\&D. In the 1980 CPS classification of occupations, these occupations are computer scientists (64-65), mathematical scientists (68), and natural scientists (69-83). The second group consists of those broadly defined as $R \& D$ workers, which includes narrowly defined R\&D workers and occupations in which a lower proportion 
of workers are doing R\&D. In the 1980 census occupational classification system, they are scientists (64-65, 68, 69-83), engineers (44-62), economists (166), and designers (185). Educational qualifications are also considered. Respondents who are R\&D workers must have at least a high school degree (Note 16). The rest of the skilled workers are simply white-collar workers.

The regression results under the narrow definition of R\&D workers can be thought of as lower-bound results, and those under the broad definition of R\&D workers can be thought of as upper-bound results. The broad definition of $R \& D$ may cause estimation problems if a considerable fraction of engineers, economists, and designers are not doing R\&D jobs. The narrow definition of R\&D may cause underestimation if, in fact, most engineers, economists, and designers are R\&D workers. Thus, comparing results from both specifications can give us a better answer to the questions. Intuitively speaking, there were fewer engineers, economists, and designers in the 1970s. Those people who are hired in manufacturing industries have a higher probability of doing $R \& D$. Therefore, it is expected that the broad definition should be suitable for cases in the 1970s and the narrow definition should be more suitable for cases in the 1980s.

\subsection{The Division Procedure}

The division procedure can be separated into two parts. First, by employing the March CPS supplement, this study computes both the R\&D workers' and white-collar workers' shares in total skilled laborers' employment and wage by industries. If the data year is later than 1976, R\&D workers' and white-collar workers' shares in total skilled laborers' working hours are also computed. The average of working hours of all skilled workers in each industry is also needed for converting employment data of non-production labor in the NBER Productivity Database into working-hour data.

Second, when the R\&D workers' and white-collar workers' shares in total skilled laborers' employment and wages are multiplied by wage payment and number of non-production workers in the NBER Productivity Database, the products are R\&D workers' wage payment, the white-collar workers' wage payment, the number of employed R\&D workers, and the number of white-collar workers. R\&D and white-collar workers' wages are wage payments to R\&D and white-collar workers divided by the number of employed R\&D and white-collar workers.

As for the data after 1976, employment data of non-production workers from the NBER Productivity Database are multiplied by average working hours of all skilled workers from the March CPS supplement to get skilled laborers' hourly data. Then, the second step is redone with R\&D workers' and white-collar workers' shares in working hours computed from the March CPS supplement to get the hourly wages and employment for R\&D workers and white-collar workers. Last, the data for blue-collar workers are those for production workers in the NBER Productivity Database.

\subsection{Data Summary}

Table 1 gives summary statistics for workers' data, which I constructed from the NBER Productivity Database and the CPS for 1972-1979 and 1979-1990. R\&D workers, who have high-technology skills and are usually well educated, should be expected to receive the highest pay among workers studied. The numbers in Table 1 confirm this idea. In each period, R\&D workers get the highest average pay per year. If hourly data is employed, R\&D workers still get the highest pay per hour. Annual changes of workers' wages in 1972-1979 tell almost the same story. R\&D workers' pay grew the most rapidly in that time period. During 1979-1990, however, according to the data counting workers by numbers of workers employed, R\&D workers' pay did not grow the most rapidly. In fact, their pay in 1979-1990 grew the most slowly under the broad definition of R\&D workers. If the narrow definition of R\&D workers and hourly data are used, R\&D workers' pay still grew the most rapidly.

Table 1. Summary statistics

\begin{tabular}{lcccc}
\hline & \multicolumn{2}{c}{$1972-1979$} & \multicolumn{2}{c}{$1979-1990$} \\
& $\begin{array}{c}\text { Average } \\
\text { (USD/year) }\end{array}$ & $\begin{array}{c}\text { Annual } \\
\text { change }\end{array}$ & $\begin{array}{c}\text { Average USD/year } \\
\text { or (USD/hour) }\end{array}$ & $\begin{array}{c}\text { Annual change USD/year } \\
\text { or (USD/hour) }\end{array}$ \\
\hline $\begin{array}{l}\text { Average of and change in workers' prices: } \\
\text { Blue-collar workers }\end{array}$ & 11443 & 7.460 & 19641 & 4.964 \\
& & & $(10)$ & $(4.705)$ \\
Non-production workers & 16648 & 7.201 & 29324 & 5.432 \\
& & & $(14)$ & $(5.025)$ \\
\hline
\end{tabular}




\begin{tabular}{|c|c|c|c|c|}
\hline White-collar workers: & 15666 & 7.052 & 27438 & 5.517 \\
\hline Under the broad definition of R\&D workers & & & (13) & $(5.060)$ \\
\hline White-collar workers: & 16449 & 7.179 & 28939 & 5.441 \\
\hline Under the narrow definition of R\&D workers & & & (14) & $(4.980)$ \\
\hline R\&D workers: & 21571 & 7.668 & 37076 & 4.780 \\
\hline Under the broad definition of $R \& D$ workers & & & $(26)$ & $(4.074)$ \\
\hline R\&D workers: & 20665 & 7.741 & 34159 & 4.843 \\
\hline Under the narrow definition of R\&D workers & & & $(32)$ & $(6.160)$ \\
\hline Factor cost-shares: & $\begin{array}{l}\text { Average } \\
\text { (percent) }\end{array}$ & $\begin{array}{l}\text { Annual } \\
\text { change }\end{array}$ & $\begin{array}{l}\text { Average } \\
\text { (percent) }\end{array}$ & Annual change \\
\hline Blue-collar workers & 12.470 & -0.299 & 10.185 & -0.152 \\
\hline Non-production workers & 6.653 & -0.201 & 6.442 & -0.006 \\
\hline $\begin{array}{l}\text { White-collar workers: } \\
\text { Under the broad definition of R\&D workers }\end{array}$ & 5.292 & -0.113 & 4.984 & -0.009 \\
\hline $\begin{array}{l}\text { White-collar workers: } \\
\text { Under the narrow definition of R\&D workers }\end{array}$ & 6.399 & -0.129 & 6.194 & 0.002 \\
\hline $\begin{array}{l}\text { R\&D workers: } \\
\text { Under the broad definition of } R \& D \text { workers }\end{array}$ & 1.361 & -0.024 & 1.458 & 0.022 \\
\hline $\begin{array}{l}\text { R\&D workers: } \\
\text { Under the narrow definition of } R \& D \text { workers } \\
\text { TFP : }\end{array}$ & 0.253 & -0.009 & 0.248 & -0.001 \\
\hline $\begin{array}{l}\text { Broad R\&D workers definition } \\
\text { (hourly data) }\end{array}$ & & 0.587 & & $\begin{array}{c}0.864 \\
(0.880)\end{array}$ \\
\hline $\begin{array}{l}\text { Narrow R\&D workers definition } \\
\text { (hourly data) }\end{array}$ & & 0.537 & & $\begin{array}{c}0.839 \\
(0.913)\end{array}$ \\
\hline
\end{tabular}

Note. Numbers in parentheses are calculated from hourly data. Workers' average wages are computed over the first and last year of each period and weighted by the industry share of total manufacturing payments to that factor. Those numbers are USD per person per year, or per hour, if hourly data are used. The annual change in TFP is weighted by the industry share of total manufacturing shipments. Numbers of TFP are computed from primary factors - blue-collar workers, white-collar workers, and capital—R\&D workers are excluded. See Feenstra and Hanson (1996) for the rest of the summaries of variables, such as outsourcing and capital services.

It is not surprising that low-skilled labor (blue-collar workers) got the lowest pay during these two decades. The annual change, however, was greater than that experienced by white-collar workers and non-production workers in 1972-1979. Note that the difference in annual change between white-collar and blue-collar workers in 19791990 is smaller when using hourly data. Feenstra and Hanson's (1999) study counted the numbers of employed workers in the non-production workers category and working-hour data in the production workers category. If hourly data of non-production workers are employed, it may be possible to get a weaker effect of outsourcing on relative wage of non-production workers.

The second part of Table 1 contains summaries of workers' cost share in industry's value of shipment. Both production and non-production workers' share in costs were decreasing, but R\&D workers were relatively stable in their cost shares. Following Feenstra and Hanson (1999), this study measures total factor productivity (TFP) by using the primal Tornqvist index, which equals the log change of output minus the share-weighted log change of primary inputs. Primary factors in Feenstra and Hanson (1999) are non-production workers, production workers, and capital, but in this paper they are white-collar workers, blue-collar workers, and capital. From the bottom line of Table 1 it can be seen that TFP grew much faster in the 1980s than the TFP in the 1970s, including some possible R\&D workers' increased TFP. In this study, the wage cost of R\&D should be thought of as a sunk cost spent by producers before they manufacture their product. Thus, value-added prices in this study are also different from those in Feenstra and Hanson (1999).

Real output and the capital/output ratio can be computed from the NBER Productivity Database. There are two prices employed in computing computer share and high-tech share (difference). They are ex post rental price and ex ante rental price (Note 17). Note that since computer share and high-tech share are only available at the two-digit SIC level, the wage regressions allow the errors to be correlated across four-digit industries with each two-digit industry. Furthermore, since this paper converts the CPS industrial classification into the three-digit SIC, a dummy variable that corresponds to the three-digit CPS industrial classification is needed to capture the grouping effects. 


\section{Results}

\subsection{Results of R\&D Workers' Wage Regressions}

Starting with the same period used by Feenstra and Hanson (1999), Table 2 illustrates the regression of changes in R\&D workers' wages from 1979 to 1990 . NP stands for non-production workers; BRD is the broad definition of R\&D workers, and NRD is the narrow definition of R\&D workers. Before non-production workers are split off, neither outsourcing (narrow) nor outsourcing (difference) had a significant positive effect on the change in non-production workers' wages. After filtering R\&D workers from non-production workers, outsourcing (narrow) had a significant positive effect on the changes in R\&D workers' wages. Therefore, this study finds some evidence to support the idea that outsourcing increased R\&D workers' wages during 1979-1990. As for other independent variables, only high-tech share (difference) had significantly positive effects on the change in R\&D workers' wage. It can be concluded that outsourcing was a main factor of raising R\&D workers' wages in 19791990.

The argument that outsourcing raises R\&D workers' wages is robust if $R \& D$ workers' wages were also affected by outsourcing significantly in 1972-1979. Feenstra and Hanson (1996) found that outsourcing had an insignificantly negative effect on non-production workers' shares in the wage bill in 1972-1979 (Note 18). If R\&D workers' wages, as Hsu (2011) predicts, benefit from outsourcing, separating R\&D workers from other non-production workers can show why not all skilled labor was hurt by outsourcing. In Table 3, no matter which definition of R\&D workers is employed, outsourcing (narrow) had a positive significant effect on R\&D workers' wages. Computers in this period had a significantly negative effects on the wages of $R \& D$ workers narrowly definition. The change in log real output and change in log capital/output ratio had a significantly negative effect on the wage of R\&D workers' wages broadly definition.

Table 2. Changes in the R\&D workers' wage: 1979-1990

\begin{tabular}{|c|c|c|c|c|c|c|}
\hline \multicolumn{7}{|c|}{ Dependent variables: annual wage-changes per working hour } \\
\hline & $\mathrm{NP}$ & $\mathrm{BRD}$ & NRD & $\mathrm{NP}$ & $\mathrm{BRD}$ & NRD \\
\hline \multicolumn{7}{|l|}{ Independent variables: } \\
\hline \multirow{2}{*}{ Outsourcing (narrow) } & 0.415 & 0.853 & 4.626 & 0.420 & 0.583 & 4.782 \\
\hline & $(1.33)$ & $(0.64)$ & $(2.07)$ & $(1.43)$ & $(0.40)$ & $(2.16)$ \\
\hline \multirow{2}{*}{ Outsourcing (difference) } & -0.326 & 0.378 & -0.149 & -0.307 & -0.372 & 0.451 \\
\hline & $(1.67)$ & $(0.24)$ & $(0.04)$ & $(1.65)$ & $(0.20)$ & $(0.11)$ \\
\hline \multicolumn{7}{|c|}{ Capital services (ex post rental prices): } \\
\hline \multirow{2}{*}{ Computer share } & -0.195 & -5.640 & -3.650 & & & \\
\hline & $(0.56)$ & $(1.59)$ & $(0.84)$ & & & \\
\hline \multirow{2}{*}{ High-tech share (difference) } & 0.639 & -0.594 & 7.299 & & & \\
\hline & $(1.30)$ & $(0.19)$ & $(0.84)$ & & & \\
\hline \multicolumn{7}{|c|}{ Capital services (ex ante rental prices): } \\
\hline \multirow{2}{*}{ Computer share } & & & & -0.214 & -4.506 & 10.969 \\
\hline & & & & $(0.45)$ & $(0.57)$ & $(1.24)$ \\
\hline \multirow{2}{*}{ High-tech share (difference) } & & & & 1.648 & 2.866 & 13.414 \\
\hline & & & & $(7.46)$ & $(0.79)$ & $(2.00)$ \\
\hline \multirow{2}{*}{$\Delta \ln (y)$} & 0.051 & 0.343 & -0.014 & 0.042 & 0.253 & -0.389 \\
\hline & $(1.76)$ & $(1.40)$ & $(0.02)$ & $(1.78)$ & $(1.00)$ & $(0.49)$ \\
\hline \multirow{2}{*}{$\Delta \ln (k / y)$} & -0.004 & 0.372 & -0.198 & -0.009 & 0.224 & -0.686 \\
\hline & $(0.08)$ & $(0.82)$ & $(0.22)$ & $(0.17)$ & $(0.54)$ & $(0.69)$ \\
\hline \multirow{2}{*}{ Constant } & 0.046 & 0.044 & 0.062 & 0.044 & 0.033 & 0.043 \\
\hline & (20.84) & $(1.76)$ & $(1.01)$ & (26.74) & $(1.26)$ & $(0.72)$ \\
\hline$R^{2}$ & 0.088 & 0.015 & 0.039 & 0.127 & 0.007 & 0.058 \\
\hline $\mathrm{N}$ & 445 & 445 & 445 & 445 & 445 & 445 \\
\hline
\end{tabular}

Note. Dependent variables NP are the changes of all non-production workers' wages. Dependent variables BRD are the changes of R\&D workers' wages, which are measured according to the broad definition. Dependant variable NRD is the changes of R\&D workers' wages, which is measured according to the narrow definition. Numbers in parentheses are the absolute values of $t$ statistics; standard errors in all regressions are robust to heteroskedasticity and correlation in the errors within two-digit industry groups. Besides, a dummy variable, which is the 1980 CPS industry classification, is also included in each regression. All dependent and independent variables are measured as annual changes and weighted by average industry share of all manufacturing wage bills. 
Table 3. Changes in the R\&D workers' wage: 1972-1979

\begin{tabular}{|c|c|c|c|c|c|c|}
\hline \multicolumn{7}{|c|}{ Dependent variable: annual wage-changes per capita } \\
\hline & $\mathrm{NP}$ & BRD & NRD & $\mathrm{NP}$ & $\mathrm{BRD}$ & NRD \\
\hline \multicolumn{7}{|l|}{ Independent variables: } \\
\hline Outsourcing (narrow) & $\begin{array}{c}-0.168 \\
(0.84)\end{array}$ & $\begin{array}{l}1.232 \\
(3.14)\end{array}$ & $\begin{array}{l}1.943 \\
(2.28)\end{array}$ & $\begin{array}{l}-0.070 \\
(0.40)\end{array}$ & $\begin{array}{l}1.480 \\
(3.40)\end{array}$ & $\begin{array}{l}2.304 \\
(2.39)\end{array}$ \\
\hline Outsourcing (difference) & $\begin{array}{l}-0.152 \\
(1.47)\end{array}$ & $\begin{array}{l}0.113 \\
(0.47)\end{array}$ & $\begin{array}{l}1.100 \\
(1.92)\end{array}$ & $\begin{array}{l}-0.126 \\
(1.14)\end{array}$ & $\begin{array}{l}0.089 \\
(0.33)\end{array}$ & $\begin{array}{l}1.021 \\
(2.07)\end{array}$ \\
\hline \multicolumn{7}{|c|}{ Capital services (ex post rental prices): } \\
\hline Computer share & $\begin{array}{l}-0.027 \\
(0.06)\end{array}$ & $\begin{array}{l}0.042 \\
(0.05)\end{array}$ & $\begin{array}{l}-5.033 \\
(2.13)\end{array}$ & & & \\
\hline High-tech share (difference) & $\begin{array}{l}0.785 \\
(2.65)\end{array}$ & $\begin{array}{l}1.750 \\
(1.93)\end{array}$ & $\begin{array}{l}0.836 \\
(0.81)\end{array}$ & & & \\
\hline \multicolumn{7}{|c|}{ Capital services (ex ante rental prices): } \\
\hline Computer share & & & & $\begin{array}{l}0.270 \\
(0.42)\end{array}$ & $\begin{array}{l}0.519 \\
(0.26)\end{array}$ & $\begin{array}{l}-9.615 \\
(1.98)\end{array}$ \\
\hline High-tech share (difference) & & & & $\begin{array}{l}1.155 \\
(2.43)\end{array}$ & $\begin{array}{l}1.742 \\
(1.95)\end{array}$ & $\begin{array}{l}0.384 \\
(0.30)\end{array}$ \\
\hline$\Delta \ln (y)$ & $\begin{array}{l}-0.020 \\
(0.53)\end{array}$ & $\begin{array}{l}-0.187 \\
(2.62)\end{array}$ & $\begin{array}{l}-0.131 \\
(0.75)\end{array}$ & $\begin{array}{l}-0.017 \\
(0.47)\end{array}$ & $\begin{array}{l}-0.180 \\
(2.34)\end{array}$ & $\begin{array}{c}-0.092 \\
(0.53)\end{array}$ \\
\hline$\Delta \ln (k / y)$ & $\begin{array}{l}-0.006 \\
(0.14)\end{array}$ & $\begin{array}{l}-0.257 \\
(4.16)\end{array}$ & $\begin{array}{l}-0.057 \\
(0.27)\end{array}$ & $\begin{array}{l}-0.005 \\
(0.13)\end{array}$ & $\begin{array}{l}-0.258 \\
(4.16)\end{array}$ & $\begin{array}{r}-0.033 \\
(0.16)\end{array}$ \\
\hline Constant & $\begin{array}{c}0.075 \\
(19.69)\end{array}$ & $\begin{array}{c}0.072 \\
(11.12)\end{array}$ & $\begin{array}{l}0.068 \\
(5.15)\end{array}$ & $\begin{array}{c}0.076 \\
(19.86)\end{array}$ & $\begin{array}{c}0.074 \\
(11.57)\end{array}$ & $\begin{array}{l}0.069 \\
(5.03)\end{array}$ \\
\hline$R^{2}$ & 0.082 & 0.086 & 0.135 & 0.100 & 0.076 & 0.155 \\
\hline $\mathrm{N}$ & 445 & 445 & 445 & 445 & 445 & 445 \\
\hline
\end{tabular}

Note. Dependent variable NP is the changes of all non-production workers' wages. Dependent variable BRD is the changes of R\&D workers' wages, which is measured in broad definition. Dependent variable NRD is the changes of R\&D workers' wages, which is measured in narrow definition. Numbers in parentheses are the absolute values of $t$ statistics and standard errors in all regressions are robust to heteroskedasticity and correlation in the errors within two-digit industry groups. Besides, a dummy variable, the 1980 CPS industry classification, is also included in each regression. All dependent and independent variables are measured as annual changes and weighted by average industry share of all manufacturing wage bills.

\subsection{Results of Two-Stage Regression}

The data set of this study includes two measures of R\&D workers and two measures of foreign outsourcing. Numbers of production hours for all blue-collar workers and skilled labor are available for 1979 through 1990. The results of the R\&D workers' wage regressions indicate that the narrow definition of R\&D workers should be applied in the study of the 1980s and the broad definition of R\&D workers should be applied in the study of the 1970s (Note 19). Thus, in the period from 1979 to 1990, this paper only reports the regression results if the narrow definition of R\&D workers is applied. From 1972 to 1979, only the regression results under the broad definition of $\mathrm{R} \& \mathrm{D}$ workers are reported.

In each table of first-stage regression, there are four different regressions. The first two regressions employ ex ante rental prices in computing high-tech capital shares, and the other two regressions use ex post rental prices. In each of the two regressions, the basic regression is ordered first and a regression including R\&D factors comes second. The basic regression includes all structural variables in Feenstra and Hanson (1999) as independent variables. In the results of the second-stage regression, this study focuses mainly on the effects from outsourcing. The results of R\&D factors are also another focus. The coefficients of the difference between white-collar and blue-collar workers show the changes of the relative wage of white-collar workers.

The order and brief description of tables is as follows: Tables 4 and 5 are first-stage regressions using data in 1979-1990. The regressions in Table 4 use the number of production workers, and those in Table 5 use the number of production hours in skilled labor. Table 6 reports results of the second-stage regression regarding the effects from outsourcing and R\&D factors during 1979-1990. Next, Table 7 is first-stage regressions using data in 1972-1979. Table 8 reports the results of second-stage regressions regarding the effects from outsourcing in 1972-1979 (Note 20). The letter $n$ denotes narrowly defined R\&D workers, i.e., the value-added price plus ETFP 
computed from all primary factors excluding the narrowly defined R\&D workers. The letter $b$ represents broadly defined R\&D workers, i.e., the value-added price, plus ETFP computed from all primary factors excluding the broadly defined R\&D workers. The letter $h$ represents the usage data of the number of production hours in skilled labor.

The question of whether outsourcing and R\&D factors were non-neutral technological progress in 1979-1990 can be answered by Table 4. As expected, all coefficients of outsourcing (narrow) are positive. The effects of outsourcing (difference) might be significant, depending on the price this study employs in measuring high-tech capital share; outsourcing (narrow) has a significant positive effect on dependent variables. Computers also can raise value-added prices plus ETFP, if ex post rental prices are applied, but the positive effect vanished with different measuring prices. $R \& D$ factors are significantly positive in all specifications.

Table 4. First-stage regression using employment data 1979-1990

\begin{tabular}{|c|c|c|c|c|}
\hline \multicolumn{5}{|c|}{ Dependent variable: change in value-added prices plus effective TFP } \\
\hline & $4 \mathrm{n} .1$ & $4 \mathrm{n} .2$ & $4 \mathrm{n} .3$ & $4 \mathrm{n} .4$ \\
\hline \multicolumn{5}{|l|}{ Independent variables: } \\
\hline Outsourcing (narrow) & $\begin{array}{l}0.087 \\
(2.42)\end{array}$ & $\begin{array}{l}0.085 \\
(2.36)\end{array}$ & $\begin{array}{l}0.073 \\
(2.10)\end{array}$ & $\begin{array}{l}0.072 \\
(2.12)\end{array}$ \\
\hline Outsourcing (difference) & $\begin{array}{l}0.098 \\
(2.55)\end{array}$ & $\begin{array}{l}0.096 \\
(2.64)\end{array}$ & $\begin{array}{l}0.068 \\
(1.60)\end{array}$ & $\begin{array}{l}0.067 \\
(1.69)\end{array}$ \\
\hline \multicolumn{5}{|c|}{ Capital services (ex ante rental prices): } \\
\hline Computer share & $\begin{array}{l}0.198 \\
(1.84)\end{array}$ & $\begin{array}{l}0.196 \\
(1.87)\end{array}$ & & \\
\hline High-tech share (difference) & $\begin{array}{r}-0.093 \\
(1.12)\end{array}$ & $\begin{array}{c}-0.099 \\
(1.22)\end{array}$ & & \\
\hline \multicolumn{5}{|c|}{ Capital services (ex post rental prices): } \\
\hline Computer share & & & $\begin{array}{l}0.154 \\
(2.31)\end{array}$ & $\begin{array}{l}0.153 \\
(2.35)\end{array}$ \\
\hline High-tech share (difference) & & & $\begin{array}{l}0.053 \\
(0.67)\end{array}$ & $\begin{array}{l}0.052 \\
(0.64)\end{array}$ \\
\hline R\&D factors & & $\begin{array}{l}0.654 \\
(2.79)\end{array}$ & & $\begin{array}{l}0.595 \\
(2.23)\end{array}$ \\
\hline Constant & $\begin{array}{c}0.042 \\
(80.00)\end{array}$ & $\begin{array}{c}0.042 \\
(80.77)\end{array}$ & $\begin{array}{c}0.042 \\
(78.93)\end{array}$ & $\begin{array}{c}0.042 \\
(80.47)\end{array}$ \\
\hline$R^{2}$ & 0.198 & 0.214 & 0.226 & 0.240 \\
\hline $\mathrm{N}$ & 445 & 445 & 445 & 445 \\
\hline
\end{tabular}

Note. Dependent variables are computed from primary factors, excluding R\&D workers in the narrow definition. Numbers in parentheses are the absolute values of $t$ statistics; standard errors in all regressions are robust to heteroskedasticity and correlation in the errors within two-digit industry groups. Besides, a dummy variable, the 1980 CPS industry classification, is also included in each regression. All variables are measured as annual changes and weighted by average industry share of all manufacturing shipments.

This study also employs hourly data of white-collar workers in this period. The results in Table 5 , when compared with those of Table 4, show that the significant coefficients of outsourcing (narrow) become weak. These results are sensible, since the difference of annual change in wages between blue-collar and white-collar workers is smaller when using hourly data than when using employment data. Outsourcing is once again a significant factor when ex ante rental prices are applied. R\&D factors are significant in all kinds of specifications.

In sum, there are two findings from the first-stage regressions of 1979-1990. First, regarding the narrow definition of $R \& D$ workers, outsourcing (narrow) had a significantly positive effect on value-added prices plus ETFP. Second, R\&D factors, which are subtracted from R\&D workers' payment share in the industry's value of shipment, increased value-added price plus ETFP significantly. Computer share also had a significantly positive effect on dependent variables, but rental price used for measuring capital shares also matters. 
Table 5. First-stage regression using hourly data in 1979-1990

\begin{tabular}{|c|c|c|c|c|}
\hline \multicolumn{5}{|c|}{ Dependent Variable: changes in value-added prices plus effective TFP effective TFP } \\
\hline & $5 \mathrm{nh} .1$ & $5 \mathrm{nh} .2$ & $5 \mathrm{nh} .3$ & 5nh.4 \\
\hline \multicolumn{5}{|l|}{ Independent variables: } \\
\hline Outsourcing (narrow) & $\begin{array}{l}0.066 \\
(2.19)\end{array}$ & $\begin{array}{l}0.065 \\
(2.15)\end{array}$ & $\begin{array}{c}0.056 \\
(1.91)\end{array}$ & $\begin{array}{l}0.055 \\
(1.92)\end{array}$ \\
\hline Outsourcing (difference) & $\begin{array}{l}0.075 \\
(2.22)\end{array}$ & $\begin{array}{l}0.074 \\
(2.29)\end{array}$ & $\begin{array}{l}0.053 \\
(1.42)\end{array}$ & $\begin{array}{l}0.053 \\
(1.48)\end{array}$ \\
\hline \multicolumn{5}{|c|}{ Capital services (ex ante rental prices): } \\
\hline Computer share & $\begin{array}{l}0.120 \\
(1.27)\end{array}$ & $\begin{array}{c}0.119 \\
(1.28)\end{array}$ & & \\
\hline High-tech share (difference) & $\begin{array}{l}-0.081 \\
(1.07)\end{array}$ & $\begin{array}{l}-0.085 \\
(1.15)\end{array}$ & & \\
\hline \multicolumn{5}{|c|}{ Capital services (ex post rental prices): } \\
\hline Computer share & & & $\begin{array}{l}0.108 \\
(1.96)\end{array}$ & $\begin{array}{l}0.108 \\
(1.97)\end{array}$ \\
\hline High-tech share (difference) & & & $\begin{array}{l}0.051 \\
(0.66)\end{array}$ & $\begin{array}{l}0.050 \\
(0.64)\end{array}$ \\
\hline R\&D factors & & $\begin{array}{l}0.459 \\
(3.24)\end{array}$ & & $\begin{array}{l}0.377 \\
(2.14)\end{array}$ \\
\hline Constant & $\begin{array}{c}0.042 \\
(89.21)\end{array}$ & $\begin{array}{c}0.042 \\
(89.87)\end{array}$ & $\begin{array}{c}0.041 \\
(87.69)\end{array}$ & $\begin{array}{c}0.041 \\
(88.86)\end{array}$ \\
\hline$R^{2}$ & 0.175 & 0.186 & 0.199 & 0.206 \\
\hline $\mathrm{N}$ & 445 & 445 & 445 & 445 \\
\hline
\end{tabular}

Note. Dependent variables are computed from primary factors, excluding R\&D workers according to the narrow definition. Numbers in parentheses are the absolute values of $t$ statistics; standard errors in all regressions are robust to heteroskedasticity and correlation in the errors within two-digit industry groups. Besides, a dummy variable, the 1980 CPS industry classification, is also included in each regression. All independent variables are measured as annual changes and weighted by average industry share of all manufacturing shipments.

After the first-stage regression, the second-stage regressions interpret the change of the price for primary factors due to structural variables. The results of estimating the changes of blue-collar and white-collar workers' wages due to outsourcing are reported in Table 6-1. The dependent variable for each second-stage regression comes from a first-stage regression that includes R\&D factors. Outsourcing (narrow) has significantly positive effects on white-collar workers' wages even if the hourly data are used. Furthermore, outsourcing increased the difference in wages between white-collar and blue-collar labor by raising the wages of white-collar workers (Note 21). Similar results can be seen in Table 6-2. R\&D factors raised the difference in wages between white-collar and blue-collar labor by increasing the wages of white-collar workers and decreasing the wage of blue-collar workers.

Table 6.1. Second-stage regression: estimated factor-price changes in 1979-1990

\begin{tabular}{|c|c|c|c|c|}
\hline Dependent variables (first-stage regressions): & $4 \mathrm{n} .2$ & $4 \mathrm{n} .2$ & $5 \mathrm{nh} .2$ & $5 \mathrm{nh} .2$ \\
\hline \multicolumn{5}{|c|}{ (1) Employing ex ante rental prices for computer share and high-tech share } \\
\hline $\begin{array}{l}\text { Dependent variable: change in share-weighted } \\
\text { factor prices explained by: }\end{array}$ & $\begin{array}{c}\text { Outsourcing } \\
\text { (narrow) }\end{array}$ & $\begin{array}{l}\text { Outsourcing } \\
\text { (difference) }\end{array}$ & $\begin{array}{l}\text { Outsourcing } \\
\text { (narrow) }\end{array}$ & $\begin{array}{l}\text { Outsourcing } \\
\text { (difference) }\end{array}$ \\
\hline \multicolumn{5}{|l|}{ Independent variables: } \\
\hline \multirow[t]{2}{*}{ Blue-collar labor share } & -0.011 & 0.025 & -0.009 & 0.019 \\
\hline & $(0.83)$ & $(1.65)$ & $(0.82)$ & $(1.55)$ \\
\hline \multirow[t]{2}{*}{ White-collar labor share } & 0.131 & 0.077 & 0.100 & 0.059 \\
\hline & $(2.21)$ & $(2.21)$ & $(2.04)$ & $(1.99)$ \\
\hline \multirow{2}{*}{$\begin{array}{l}\text { Difference between white-collar and blue-collar } \\
\text { share }\end{array}$} & 0.142 & 0.052 & 0.108 & 0.040 \\
\hline & $(2.13)$ & $(1.57)$ & $(1.97)$ & $(1.49)$ \\
\hline \multicolumn{5}{|c|}{ (2) Employing ex post rental prices for computer share and high-tech share } \\
\hline $\begin{array}{l}\text { Dependent variables } \\
\text { (first-stage regressions): }\end{array}$ & $4 \mathrm{n} .4$ & $4 \mathrm{n} .4$ & $5 \mathrm{nh} .4$ & $5 \mathrm{nh} .4$ \\
\hline \multirow{2}{*}{$\begin{array}{l}\text { Difference between white-collar and blue-collar } \\
\text { share }\end{array}$} & 0.120 & 0.037 & 0.092 & 0.029 \\
\hline & (1.94) & $(1.28)$ & $(1.78)$ & (1.18) \\
\hline
\end{tabular}

Note. The letters and numbers in the first row stand for the dependent variables in their first-stage regressions. All dependent variables are computed from regressions that include quadratic terms of outsourcing (narrow) and outsourcing (difference). Numbers in parentheses are the absolute values of $t$ statistics. 
Table 6.2. Second-stage regression: estimated factor-price changes in 1979-1990

\begin{tabular}{lllll}
\hline $\begin{array}{l}\text { Dependent variables (first-stage regressions): } \\
\text { Independent variables: }\end{array}$ & $4 \mathrm{n} .2$ & $4 \mathrm{n} .4$ & $5 \mathrm{nh} .2$ & $5 \mathrm{nh} .4$ \\
\hline Blue-collar labor share & -0.011 & -0.008 & -0.017 & -0.011 \\
& $(1.67)$ & $(1.44)$ & $(1.71)$ & $(1.39)$ \\
White-collar labor share & 0.033 & 0.034 & 0.051 & 0.049 \\
& $(1.96)$ & $(2.57)$ & $(2.03)$ & $(2.32)$ \\
Difference between white-collar and blue-collar share & 0.043 & 0.042 & 0.068 & 0.060 \\
\hline
\end{tabular}

Note. The letters and numbers in the first row stand for the dependent variables in their first-stage regressions. All dependent variables are computed from regressions that include R\&D factors. Numbers in parentheses are the absolute values of $t$ statistics.

One of the puzzles of outsourcing is that the phenomenon found in most empirical studies and theoretical models in the 1980s cannot be seen in the 1970s. As the regression results in Table 7 show, outsourcing, as expected, did not increase value-added prices plus ETFP, but it might actually decrease them. High-tech share had similar results as well. After skilled labor was divided into R\&D and other white-collar workers, and R\&D factors were added, outsourcing (difference) negatively influenced value-added prices plus ETFP at the $10 \%$ significance level (Note 22).

Table 7. First-stage regression using the data in 1972-1979

\begin{tabular}{|c|c|c|c|c|}
\hline \multicolumn{5}{|c|}{ Dependent variable: Change in value-added prices plus effective TFP } \\
\hline & $7 \mathrm{~b} .1$ & $7 \mathrm{~b} .2$ & $7 \mathrm{~b} .3$ & $7 \mathrm{~b} .4$ \\
\hline \multicolumn{5}{|l|}{ Independent variables: } \\
\hline \multirow{3}{*}{ Outsourcing (narrow) } & -0.004 & -0.004 & 0.000 & 0.000 \\
\hline & $(0.62)$ & $(0.72)$ & $(0.09)$ & $(0.11)$ \\
\hline & -0.008 & -0.008 & -0.009 & -0.009 \\
\hline Outsourcing (difference) & $(1.57)$ & $(1.64)$ & $(1.70)$ & $(1.75)$ \\
\hline \multicolumn{5}{|c|}{ Capital services(ex ante rental prices): } \\
\hline \multirow{2}{*}{ Computer share } & 0.009 & 0.009 & & \\
\hline & $(0.64)$ & $(0.68)$ & & \\
\hline \multirow{2}{*}{ High-tech share (difference) } & -0.007 & -0.007 & & \\
\hline & $(0.84)$ & $(0.92)$ & & \\
\hline \multicolumn{5}{|c|}{ Capital services (ex post rental prices): } \\
\hline \multirow{2}{*}{ Computer share } & & & -0.007 & -0.007 \\
\hline & & & $(0.62)$ & $(0.60)$ \\
\hline \multirow{2}{*}{ High-tech share (difference) } & & & -0.013 & -0.013 \\
\hline & & & $(1.80)$ & $(1.83)$ \\
\hline \multirow{2}{*}{$R \& D$ factors } & & 0.032 & & 0.026 \\
\hline & & $(1.71)$ & & $(1.49)$ \\
\hline \multirow{2}{*}{ Constant } & 0.072 & 0.072 & 0.072 & 0.072 \\
\hline & $(350.77)$ & $(351.29)$ & $(349.75)$ & $(350.37)$ \\
\hline$R^{2}$ & 0.041 & 0.046 & 0.054 & 0.057 \\
\hline $\mathrm{N}$ & 445 & 445 & 445 & 445 \\
\hline
\end{tabular}

Note. Dependent variables are computed from primary factors and exclude R\&D workers according to the broad definition. Numbers in parentheses are the absolute values of $t$ statistics; standard errors in all regressions are robust to heteroskedasticity and correlation in the errors within two-digit industry groups. Besides, a dummy variable, the 1980 CPS industry classification, is also included in each regression. All independent variables are measured as annual changes and weighted by average industry share of all manufacturing shipments.

In Table 8 , if the $10 \%$ significance level is applied, the wage of white-collar workers was decreased by outsourcing (difference) in the 1970s. The wages of white-collar relative to those of blue-collar workers were decreased as well. This result tells us that it is the decrease in white-collar workers' wages that deteriorated the relative wages of white-collar labor. The results of other structural variables had no significant effects on 
workers' wages.

Table 8. Second-stage regression: estimated factor-price changes, 1972-1979

\begin{tabular}{|c|c|c|}
\hline Dependent variables (first-stage regressions): & $7 \mathrm{~b} .2$ & $7 \mathrm{~b} .2$ \\
\hline \multicolumn{3}{|c|}{ (1) Employing ex post rental prices for computer share and high-tech share } \\
\hline $\begin{array}{l}\text { Dependent variable: change in share-weighted factor } \\
\text { prices explained by: }\end{array}$ & $\begin{array}{l}\text { Outsourcing } \\
\text { (narrow) }\end{array}$ & $\begin{array}{l}\text { Outsourcing } \\
\text { (difference) }\end{array}$ \\
\hline \multicolumn{3}{|l|}{ Independent variables: } \\
\hline \multirow[t]{2}{*}{ Blue-collar labor share } & 0.000 & 0.001 \\
\hline & $(0.10)$ & $(0.55)$ \\
\hline \multirow[t]{2}{*}{ White-collar labor share } & 0.000 & -0.021 \\
\hline & $(0.10)$ & $(1.68)$ \\
\hline \multirow[t]{2}{*}{ Difference between white-collar and blue-collar share } & 0.000 & -0.022 \\
\hline & $(0.10)$ & $(1.65)$ \\
\hline \multicolumn{3}{|c|}{ (2) Employing ex ante rental prices for computer share and high-tech share } \\
\hline Dependent variables (first-stage regressions): & $7 \mathrm{~b} .4$ & $7 \mathrm{~b} .4$ \\
\hline \multirow[t]{2}{*}{ Difference between white-collar and blue-collar share } & -0.004 & -0.018 \\
\hline & $(0.69)$ & $(1.56)$ \\
\hline
\end{tabular}

Note. All dependent variables are computed from regressions that include quadratic terms of outsourcing (narrow) and outsourcing (difference). The letters and numbers in the first row stand for the dependent variables in their first-stage regressions. Numbers in parentheses are the absolute value of $t$ statistics.

\section{Conclusion}

The topic of the impact of international outsourcing on wages has been discussed much by previous literature. Feenstra and Hanson $(1996 ; 1999)$ employed U.S. data, and their empirical results support the argument made by most theoretical literature that international outsourcing is one of the factors that has caused wage inequality. Feenstra and Hanson's (1996) unexpected results for 1970s could be explained by theoretical works such as Arndt (1997) and Jones (2005). However, two additional questions remain for economists. First, did all skilled labor's wages decrease due to international outsourcing in the 1970s? Second, was the dropping of the relative wage of skilled labor to unskilled labor caused by increasing the wages of unskilled labor or by decreasing the wages of skilled labor?

Hsu (2011) proposed a three-type-worker framework based on the quality ladder and product cycle model and argued that the skilled workers responsible for innovation should be affected by international outsourcing differently from skilled labor that works in the manufacturing department. To assess Hsu's (2011) idea, this study employed the NBER Productivity Database and the March CPS Supplement to construct a new data set with three kinds of labor and wage regressions and two-stage regressions in Feenstra and Hanson (1999) to see the change in U.S. workers' wages in the 1970s and 1980s. This study finds that, first, the wages of U.S. manufacturing R\&D workers were increased by international outsourcing in both 1970s and 1980s, and second, outsourcing might have decreased the relative wage of white-collar workers in the 1970s because it might have decreased the wages of white-collar workers and might had no effect on blue-collar workers' wages.

Based on the results of this study, research investigating the impact of international outsourcing on labor markets should consider the role of innovation, which lets part of the skilled labor receive effects different from those of the others. The next step is to examine the impact of globalization on wages under the framework of three types of labor. Feenstra and Hanson (1996) also found that globalization had a significantly negative effect on the wages of skilled labor relative to those of unskilled labor. R\&D workers might still benefit from globalization.

\section{References}

Arndt, S. W. (1997). Globalization and the open economy. North American Journal of Economics and Finance, 8 , 71-79. http://dx.doi.org/10.1016/S1062-9408(97)90020-6

Bartelsman, E. J., \& Gray, W. (1996). The Nber manufacturing productivity database. NBER Technical Working Paper: 205. Retrieved from http://www.nber.org/papers/t0205.pdf

Berman, E., Bound, J., \& Griliches, Z. (1994). Changes in the demand for skilled labor within U.S. manufacturing: Evidence from the annual survey of manufactures. Quarterly Journal of Economics, 109, 
367-397. http://dx.doi.org/10.2307/2118467

Berndt, E. R., \& Morrison, C. J. (1995). High-tech capital formation and economic performance in U.S. manufacturing industries: An exploratory analysis. Journal of Econometrics, 65, 9-43. http://dx.doi.org/10.1016/0304-4076(94)01596-R

Chongvilaivan, A., \& Hur, J. (2011). Outsourcing, labour productivity and wage inequality in the US: A primal approach. Applied Economics, 43, 487-502. http://dx.doi.org/10.1080/00036840802360302

Deardorff, A. V. (2001a). Fragmentation across cones. In S. W. Arndt \& H. Kierzkowski (Eds.), Fragmentation: New production patterns in the world economy (pp. 35-51). Oxford and New York: Oxford University Press.

Deardorff, A. V. (2001b). Fragmentation in simple trade models. North American Journal of Economics and Finance, 12, 121-137. http://dx.doi.org/10.1016/S1062-9408(01)00043-2

Diebold, F. X., Neumark, D., \& Polsky, D. (1997). Job stability in the United States. Journal of Labor Economics, 15, 206-233. http://dx.doi.org/10.1086/209831

Dumont, M., Rayp, G., Thas, O., \& Willeme, P. (2005). Correcting standard errors in two-stage estimation procedures with generated regressands. Oxford Bulletin of Economics and Statistics, 67, 421-433. http://dx.doi.org/10.1111/j.1468-0084.2005.00126.x

Egger, H., \& Kreickemeier, U. (2008). International fragmentation: Boon or bane for domestic employment? European Economic Review, 52, 116-132. http://dx.doi.org/10.1016/j.euroecorev.2007.01.006

Feenstra, R. C., \& Hanson, G. H. (1996). Globalization, outsourcing, and wage inequality. American Economic Review, 86, 240-245. Retrieved from http://www.aeaweb.org/aer/

Feenstra, R. C., \& Hanson, G. H. (1999). The impact of outsourcing and high-technology capital on wages: Estimates for the United States, 1979-1990. Quarterly Journal of Economics, 114, 907-940. http://dx.doi.org/10.1162/003355399556179

Geishecker, I. (2005). International outsourcing and German manufacturing wages. Schmollers Jahrbuch: Zeitschrift fur Wirtschaftsund Sozialwissenschaften. Journal of Applied Social Science Studies, 125, 87-95. Retrieved from http://ejournals.duncker-humblot.de/loi/schm

Glass, A. J., \& Saggi, K. (2001). Innovation and wage effects of international outsourcing. European Economic Review, 45, 67-86. http://dx.doi.org/10.1016/S0014-2921(99)00011-2

Grossman, G. M., \& Helpman, E. (1991). Quality ladders and product cycles. Quarterly Journal of Economics, 106, 557-586. http://dx.doi.org/10.2307/2937947

Grossman, G. M., \& Rossi-Hansberg, E. (2008). Trading tasks: A simple theory of offshoring. American Economic Review, 98, 1978-1997. http://dx.doi.org/10.1257/aer.98.5.1978

Hall, R. E., \& Jorgenson, D. W. (1967). Tax Policy and Investment Behavior. American Economic Review, 57, 391-414.

Hsieh, C. T., \& Woo, K. T. (2005). The impact of outsourcing to China on Hong Kong's labor market. American Economic Review, 95, 1673-1687. http://dx.doi.org/10.1257/000282805775014272

Hsu, K. C. (2011). Does outsourcing always benefit skilled labor? Review of International Economics, 19, 539554. http://dx.doi.org/10.1111/j.1467-9396.2011.00964.x

Jones, R. W. (2005). Immigration vs. outsourcing: Effects on labor markets. International Review of Economics and Finance, 14, 105-114. http://dx.doi.org/10.1016/j.iref.2004.08.004

Jones, R. W., \& Kierzkowski, H. (2001). Globalization and the consequences of international fragmentation. In G. A. Calvo, R. Dornbusch \& M. Obstfeld (Eds.), Money, Capital Mobility, and Trade: Essays in Honor of Robert A. Mundell (pp. 365-383). Cambridge and London: MIT Press.

Kohler, W. (2004). Aspects of international fragmentation. Review of International Economics, 12, 793-816. http://dx.doi.org/10.1111/j.1467-9396.2004.00482.x

Lawrence, R. Z., \& Slaughter, M. J. (1993). International trade and American wages in the 1980s: Giant sucking sound or small hiccup? Brookings Papers on Economic Activity, 161-210. http://dx.doi.org/10.2307/2534739

Sayek, S., \& Sener, F. (2006). Outsourcing and wage inequality in a dynamic product cycle model. Review of 
Development Economics, 10, 1-19. http://dx.doi.org/10.1111/j.1467-9361.2005.00297.x

Slaughter, M. J. (1995). Multinational corporations, outsourcing, and American wage divergence. NBER Working Papers: 5253. Retrieved from http://www.nber.org/papers/w5253.pdf

Slaughter, M. J. (2000). Production transfer within multinational enterprises and American wages. Journal of International Economics, 50, 449-472. http://dx.doi.org/10.1016/S0022-1996(98)00081-6

\section{Notes}

Note 1. Similar topics are foreign direct investment (FDI or DFI), multinational enterprise (MNE), international fragmentation, and offshoring. See Slaughter (2000) for a summary of MNEs; Jones and Kierzkowski (2001), Deardorff (2001a, 2001b), and Kohler (2004) for international fragmentation; and Grossman and Rossi-Hansberg (2008) for offshoring.

Note 2. Literature such as Lawrence and Slaughter (1993), Berman, Bound, and Griliches (1994), and Slaughter (1995) did not support the idea that outsourcing causes wage inequality. Literature that found the impacts of outsourcing on wage in addition to Feenstra and Hanson $(1996 ; 1999)$ includes Geichecker (2005) and Hsieh and Woo (2005). Chongvilaivan and Hur (2011) found the wage gap between skilled and unskilled labor can be better explained by general outsourcing than international.

Note 3. That means outsourcing can be thought as a technology improvement that makes production more skilled-labor intensive.

Note 4. The total effect of an increase in the outsourcing fraction on the Northern relative wage consists of three effects: (1) the substitution effect, which is caused by outsourcing industries shifting labor demand from the North to the South; (2) the skill effect, which can increase labor demand for white-collar workers, since outsourcing pushes firms toward skilled-labor-intensive production; (3) the scale effect, the increase in production caused by the increase in profit of outsourcing firms caused by outsourcing.

Note 5. The substitution effect and the skill effect can be seen as effects on productivity. The scale effect mainly focuses on the effect caused by an increase in consumers' total expenditure.

Note 6. Computer share measures the share of office, computing and accounting machinery in total capital. High-tech capital (difference) computes the share of communications equipment, science and engineering instruments, and photocopy and related equipment in total capital.

Note 7. In the early version of this paper, the skilled- and unskilled-labor intensities of relative outsourcing manufacturing industries were computed for U.S. data of both the 1970s and the 1980s. I found that in the 1970s the relative outsourcing industries were unskilled-labor intensive and were skilled-labor intensive in the 1980s. Thus, it is expected that in the regressions for the 1970s the impact of outsourcing on product prices was negative but positive in the regressions for the 1980s. The results are not reported here, but they are available upon request.

Note 8 . The author gratefully acknowledges the help provided by Dumont et al.

Note 9. CPS asks how many weeks the respondents worked last year and how many hours they usually worked each week during the previous year. The answers to these two questions can compose hourly data.

Note 10. Originally, there were 450 industries in the four-digit 1972 SIC. By following Feenstra and Hanson (1999), this study excludes three industries (SIC 2067, 2794, 3483) due to missing data on material purchases or prices. Additionally, data from two industries (SIC 3672, 3673) are not available in the recent version of the NBER Productivity Database.

Note 11. The 1980 census occupational classification system evolved from the Standard Occupational Classification (SOC), and the 1990 census occupational classification system was largely based on the 1980 SOC. The industrial classification system used in the 1980 census was based on the 1972 SIC, and industrial classification systems used in the 1990 census were largely based on the 1987 SIC. See the CPS Web site for detailed information.

Note 12. For consistency with the 1970 and 1990 classifications, some industries that were considered as separate in 1980 need to be merged with others. They are census code 122 (merged with 121), 211 (merged with 210), 232 (merged with 241), 301 (merged with 300), 322 (merged with 321), 332 (merged with 331), 350 (merged with 342), 362 (merged with 370), 382 (merged with 381), 390 (merged with 391), and 392 (merged with 391). 
Note 13. According to the Web site of the U.S. Census Bureau, production workers include workers (up through the line-supervisor level) engaged in fabricating, processing, assembling, inspecting, receiving, storing, handling, packing, warehousing, shipping (but not delivering), maintenance, repair, janitorial and guard services, and product development. See http://www.census.gov/mcd/asm-as1.html for details.

Note 14. The correlation coefficient of weighted shares in the wage bill from these two sources is 0.970 .

Note 15. See Feenstra and Hanson (1996) and Feenstra and Hanson (1999) for details regarding the formula for computing international outsourcing. The author thanks Feenstra and Hanson for kindly providing intermediate-material purchase data. U.S. import data can be obtained from the NBER collection.

Note 16. The education qualification in the NSF data for an R\&D worker is a college degree. Since occupations of $R \& D$ workers in this study have more variety, the education qualification in this study is lower.

Note 17. Data for high-technology capital come from the Bureau of Labor Statistics (BLS). Ex post rental prices are computed as in Hall and Jorgenson (1967). Ex ante rental prices are calculated by Berndt and Morrison (1995). All high-tech capital data in this study are kindly provided by Robert C. Feenstra and Gordon H. Hanson, who obtained the data from Catherine Morrison and Don Siegel.

Note 18. Feenstra and Hanson (1997) employed two-stage regressions to assess the impact of trade measured by foreign outsourcing on the relationship between wages of production workers and those of non-production workers in manufacturing from 1972 to 1990 . Their results for the period 1972-1979 also indicate that the effects were insignificant.

Note 19. In the period 1972-1979, outsourcing (narrow) had a significantly positive effect on both the narrow definition and broad definition of R\&D workers' wages. Since the broad definition of R\&D workers includes the narrow definition of $R \& D$ workers, the broad definition of $R \& D$ workers is more appropriate to be applied in the study of the 1970 s.

Note 20. The results of R\&D factors show that the impact was insignificant. All results are available upon request.

Note 21. In the unreported results, without non-production workers being divided into R\&D and white-collar workers, outsourcing (narrow) had a weak effect on wage inequality if hourly data are employed, while after division, outsourcing (narrow) was significant in influencing workers' wages even if hourly data are used.

Note 22. Theory and intuition predict that if the outsourcing industry is unskilled-labor intensive, the negative impact of outsourcing will be the value-added price, not the value-added price plus TFP. If I switch effective TFP from dependent variables back to independent variables, like estimation equation (6) in Feenstra and Hanson (1999), which they use to justify their approach, the coefficients of outsourcing (difference) becomes significantly negative at the 5\% significance level.

\section{Copyrights}

Copyright for this article is retained by the author(s), with first publication rights granted to the journal.

This is an open-access article distributed under the terms and conditions of the Creative Commons Attribution license (http://creativecommons.org/licenses/by/3.0/). 